\title{
Description of the immature instars of three species of Podium Fabricius (Hymenoptera, Sphecidae) from Brazil
}

\author{
Sandor Christiano Buys ${ }^{1}$, Elder Ferreira Morato ${ }^{2} \&$ Carlos Alberto Garófalo ${ }^{3}$ \\ ${ }^{1}$ Laboratório de Entomologia, Departamento de Zoologia, Universidade Federal do Rio de Janeiro. Caixa Postal 68044, \\ 21944-970 Rio de Janeiro, Rio de Janeiro, Brasil. \\ ${ }^{2}$ Laboratório de Ecologia e Comportamento de Insetos, Departamento de Biologia Geral, Universidade Federal de Minas \\ Gerais. 30161-970 Belo Horizonte, Minas Gerais, Brasil. \\ ${ }^{3}$ Departamento de Biologia, Faculdade de Filosofia, Ciências e Letras, Universidade de São Paulo. 14040-901 Ribeirão Preto, \\ São Paulo, Brasil.
}

\begin{abstract}
Immature instars of three species of the neotropical cockroach-hunting genus Podium Fabricius, 1804 are described. All larval instars and the cocoon of $P$. denticulatum Smith, 1856; the last instar and the cocoon of $P$. aureosericeum Kohl, 1902 and the last instar larva of $P$. fumigatum (Perty, 1833) were treated. The last larval instar of $P$. denticulatum is distinct from those of other species by lacking cephalic rugosity and spinning cocoons tapered in the posterior extremity. P. aureosericeum and P. fumigatum are unique in bearing small lamellae between mandibular teeth. KEY WORDS. Cocoon, larva, morphology, Neotropical, wasp.
\end{abstract}

RESUMO. São descritos estádios imaturos de três espécies do gênero neotropical caçador de baratas Podium Fabricius, 1804. Todos os estádios e o casulo de P. denticulatum Smith, 1856; a larva de último estádio e o casulo de P. aureosericeum Kohl, 1902 e a larva de último estádio de $P$. fumigatum (Perty, 1833) são tratados. A larva de último estádio de $P$. denticulatum é distinta da de outras espécies pela falta de rugosidade cefálica e por tecer casulos afilados na extremidade posterior. $P$. aureosericeum e $P$. fumigatum são únicos em possuir pequenas lamelas entre dentes mandibulares.

PALAVRAS CHAVE. Casulo, larva, morfologia, neotropical, vespa.

Podium Fabricius, 1804 is a Neotropical genus of cockroachhunting wasps, which nest in pre-existent cavities (RAU 1937, Krombein 1967, 1970, Genaro 1994, Camilo et al. 1996). Although it includes 23 described species (AMARANTE 2002), only the last instar larvae of two species have been described: P. rufipes Fabricius, 1804 (Evans \& LIN 1956) and P. luctuosum Smith, 1856 (EvANs 1964). As part of a major systematic study of Sphecidae wasps based on larvae, the last instar larvae of three species of Podium are described: $P$. denticulatum Smith 1856, P. aureosericeum Kohl, 1902, and $P$. fumigatum (Perty, 1833). The cocoons of $P$. denticulatum and $P$. fumigatum and the early instars of $P$. denticulatum are also described.

\section{MATERIAL AND METHODS}

The head and the entire body of the larvae were separately heated in $\mathrm{KOH}(10 \%)$ for about 15 minutes to eliminate the soft tissues. Several specimens were studied, but the morphometric characters were measured in only one specimen in each instar. Following the usual nomenclature, the pre-defecating fifth larval instar was named mature larva and the postdefecating fifth larval instar was named pre-pupa. Only the last instar larva of $P$. denticulatum was completely described. In the descriptions of the last larval instar of $P$. fumigatum and $P$. aureosericeum only the differences from the last larval instar of $P$. denticulatum were remarked. In a similar way, in the descriptions of the early instars of $P$. denticulatum it was remarked only the differences from the subsequent older instar.

The material was deposited in the entomological collection of Departamento de Zoologia da Universidade Federal do Rio de Janeiro, Rio de Janeiro, Brazil. Adults of $P$. fumigatum and $P$. aureosericeum reared from the collected nests were deposited in the Museu de Zoologia da Universidade de São Paulo, São Paulo, Brazil (MZUSP).

\section{RESULTS \\ Podium denticulatum Smith, 1856}

Mature larva (Figs 1-6)

Body. White, approximately cylindrical, curved; length $16 \mathrm{~mm}$; maximum width $3 \mathrm{~mm}$. Intersegmental lines weakly distinct. Prothorax with three pairs of dorsal callosities with areas lightly pigmented. Pleural lobes indistinct on thorax 
and weakly distinct on abdomen, absent on segment AX. Integument densely spinulose, spines 5-15 $\mu \mathrm{m}$ long; rare and isolated setae on all the body, 13-16 $\mu \mathrm{m}$ long; prothoracic callosities without spines, with setae. Spiracles pigmented; $113 \mu \mathrm{m}$ in diameter, all about the same size; wall ornamented with polygonal sculptures; opening into the subatrium armed with spines; peritreme unpigmented. Anus a transverse sub-apical slit.

Head. Height $1.1 \mathrm{~mm}$, width $1.1 \mathrm{~mm}$. Coronal suture distinct. Parietal bands pigmented, $250 \mu \mathrm{m}$ long. Antennal orbits lightly pigmented; with three sensilla; ovoid; $70 \mu \mathrm{m}$ in height and $55 \mu \mathrm{m}$ in width. Antennal, frontal, and clypeal concavities pigmented, clypeal one very shallow. Cephalic rugosity absent. Coronal area with 11 punctures, about $5 \mu \mathrm{m}$ in diameter, and six setae, 13-15 $\mu \mathrm{m}$ long. Frontal area with six punctures, about $5 \mu \mathrm{m}$ in diameter, and one seta, $13 \mu \mathrm{m}$ long. Genal area with about 25 punctures, 5-6 $\mu \mathrm{m}$ in diameter, and five setae, up to $25 \mu \mathrm{m}$ long. Clypeal area with 20-25 punctures, 5-7 $\mu \mathrm{m}$ in diameter, and 15 setae, 8-20 $\mu \mathrm{m}$ long. Anterior tentorial arms, hypostoma and pleurostoma pigmented, posterior thickening of the head capsule unpigmented.

Mouthparts. Labrum bilobed; $200 \mu \mathrm{m}$ in height, $440 \mu \mathrm{m}$ in width; with about 50 punctures, $6-8 \mu \mathrm{m}$ in diameter, 29 setae, 10-25 $\mu \mathrm{m}$ long, and several small basiconic sensilla on lateral and marginal portions; margin with 20 pigmented barrel-shaped sensilla, about $18 \mu \mathrm{m}$ wide, longer toward the median portion, up to $12 \mu \mathrm{m}$ long. Epipharynx with spines on lateral, marginal, and median portions, smaller on the base and gradually longer toward the margin, up to $13 \mu \mathrm{m}$ long, spines on median portion thinner and shorter, up to $10 \mu \mathrm{m}$ long; sensorial area very lightly pigmented, with six basiconic sencilla, about $5 \mu \mathrm{m}$ in diameter. Mandibles pigmented, darker in the apical portion; $450 \mu \mathrm{m}$ long; with four teeth; basal portion with two punctures and 1-2 conspicuous setae, $18 \mu \mathrm{m}$ long. Maxillae with a pigmented ring near to the apex; lateral and ventral portions with about 10 setae, up to $23 \mu \mathrm{m}$ long; inner and dorsal portions densely covered with scale-like structures, each scale with acute papillae marginally, up to $5 \mu \mathrm{m}$ long; maxillary palpi, pigmented, conical, $55 \mu \mathrm{m}$ long, $30 \mu \mathrm{m}$ wide; galeae pigmented, conical, $83 \mu \mathrm{m}$ long, 53 $\mu \mathrm{m}$ wide; lacinial area densely with curved spines, up to $15 \mu \mathrm{m}$ long. Labium pigmented in superior margin; dorsal portion strongly papillosae; margin with setae, up to $20 \mu \mathrm{m}$ long; labial palpi pigmented, conical, $53 \mu \mathrm{m}$ long, $33 \mu \mathrm{m}$ wide; spinneret a transversal slit, protected by lips with densely papillose fringes.

Morphological variation. The thoracic pleural lobes varies from indistinct to slight distinct. The basal margin of the third mandibular tooth was weakly serrated in only one examined specimen. The epipharyngeal spines sometimes extend beyond the margin. The degree of pigmentation of the head capsule is variable, but in general follows the same pattern of distribution in different specimens.

\section{Pre-pupa (Figs 7-8)}

Body more compacted than those of the mature larvae. Pleural lobes conical, developed on abdomen, indistinct on thorax. Intersegmental lines sharply defined. Other features as in mature larva.

\section{Fourth instar (Figs 9-11)}

Body. Length $6.5 \mathrm{~mm}$; maximum width about $1.3 \mathrm{~mm}$. Prothoracic dorsal callosities absent. Pleural lobes indistinct. Integument without spines or setae. Spiracles with $65 \mu \mathrm{m}$ in diameter. The anus is not sharply distinct, but an anal sulcus is visible. Other features as in mature larva.

Head. Height about $1 \mathrm{~mm}$; width $1 \mathrm{~mm}$. Coronal suture weakly distinct. Parietal bands $188 \mu \mathrm{m}$ long. Antennal orbits $40 \mu \mathrm{m}$ in height and $50 \mu \mathrm{m}$ wide. Antennal, frontal, and clypeal concavities unpigmented. Punctures and setae absent. Anterior tentorial arms and hypostoma lightly pigmented, pleurostoma unpigmented; posterior thickening of the head capsule pigmented. Other features as in mature larva.

Mouthparts. Labrum about $150 \mu \mathrm{m}$ in height; with few sparse punctures, setae absent; margin somewhat pigmented, with about 10 pigmented barrel-shaped sencilla, $5 \mu \mathrm{m}$ long and $15 \mu \mathrm{m}$ wide. Epipharyngeal spines up to $10 \mu \mathrm{m}$ long, absent on median portion; sensorial area indistinct. Mandibles lightly pigmented, $400 \mu \mathrm{m}$ long; with three apical teeth, about 15 denticles basad to the third tooth; punctures and setae absent. Maxillary palpi lightly pigmented, $50 \mu \mathrm{m}$ long and 35 $\mu \mathrm{m}$ wide; galeae lightly pigmented; $88 \mu \mathrm{m}$ long, $53 \mu \mathrm{m}$ wide; punctures and setae absent. Dorsal portion of the labium not papillose, with spines 3-5 $\mu \mathrm{m}$ long; labial palpi unpigmented; $40 \mu \mathrm{m}$ long, $13 \mu \mathrm{m}$ wide. Spinnerets indistinct; labial projection absent. Other features as in mature larva.

\section{Third instar (Figs 12-15)}

Body. Length $5 \mathrm{~mm}$; width $1 \mathrm{~mm}$. Spiracles about $45 \mu \mathrm{m}$ in diameter. Anal sulcus indistinct.

Head. Height $750 \mu \mathrm{m}$; width $750 \mu \mathrm{m}$. Coronal suture and parietal bands absent. Anntenal orbits unpigmented, very weakly distinct. Other features as in fourth instar.

Mouthparts. Labrum approximately quadrangular; height $150 \mu \mathrm{m}$, width $320 \mu \mathrm{m}$; with a few very inconspicuous punctures; lateral and marginal portions with some weakly distinguishable, unpigmented, basiconic sencilla, about $2 \mu \mathrm{m}$ in diameter; barrel-shaped sencilla absent. Epipharyngeal spines up to $5 \mu \mathrm{m}$ long on lateral and marginal portions, more sparse than in the fourth instar; some sensilla similar to those of labrum are present. Mandibles about $310 \mu \mathrm{m}$ long; three apical teeth, each divided in several small denticles, several additional denticles apically on the external margin; very lightly pigmented, the denticles a few darker. Maxillae without scale-like structures, with spine 2-3 $\mu \mathrm{m}$ long, more sparse than in the fourth instar; maxillary palpi $38 \mu \mathrm{m}$ long, $30 \mu \mathrm{m}$ wide; galeae $58 \mu \mathrm{m}$ long, $40 \mu \mathrm{m}$ wide; lacinial area sharply prominent, spines up to $5 \mu \mathrm{m}$ long. Frontal portion of the labium with a prominent central spinulose area, spines 3-5 $\mu \mathrm{m}$ long; labial palpi $14 \mu \mathrm{m}$ long, $30 \mu \mathrm{m}$ wide. Other features as in fourth instar. 

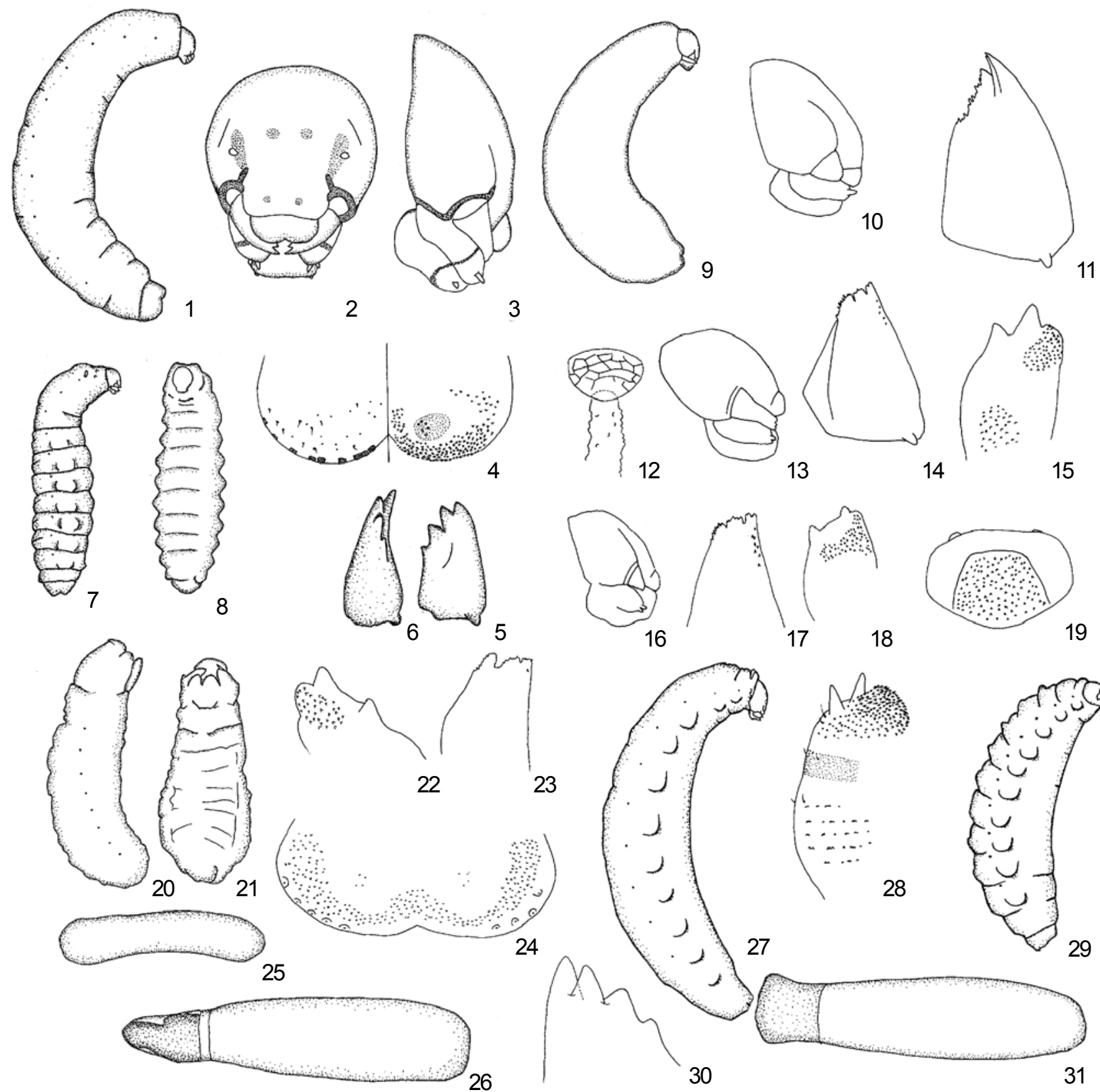

26

Figures 1-31. (1-8) Podium denticulatum. (1-6) Mature larva: (1) body, lateral view; (2-3) head, frontal and lateral views; (4) labrum and epipharynx, frontal view; (5-6) mandible, dorsal and inner views; (7-8) pre-pupa body lateral and ventral views; (9-19) Podium denticulatum. (9-11) Fourth instar: (9) body, lateral view; (10) head, lateral view; (11) mandible, dorsal view; (12-15) third instar: (12) spiracle, lateral view; (13) head, lateral view; (14) mandible, as seen in frontal view of the head; (15) maxilla, dorsal view; (16-19) Second instar: (16) head, lateral view; (17) superior portion of the mandible, frontal view; (18) maxilla, dorsal view; (19) labium, dorsal view; (20-26) Podium denticulatum: (20-24) first instar: (20-21) body lateral and ventral views; (22) superior portion of the maxilla, dorsal view; (23) superior portion of the mandible, dorsal view; (24) epipharynx, frontal view; (25) egg, lateral view; (26) cocoon, lateral view; (27-29) Podium aureosericeum: (27-28) mature larva: (27) body, lateral view; (28) maxilla, dorsal view; (29) pre-pupa body, lateral view. (30-31) Podium fumigatum: (30) apical portion of the mandible, dorsal view; (31) cocoon, lateral view. 


\section{Second instar (Figs 16-19)}

Body. Length $4 \mathrm{~mm}$, width $1 \mathrm{~mm}$. Spiracles somewhat conical; about $35 \mu \mathrm{m}$ in diameter; opening into the sub-atrium apparently not armed with spines; atrium wall ornamented with small pigmented grains, sometimes forming polygonal sculptures. Other features as in the third instar.

Head. Height about $650 \mu \mathrm{m}$; width $650 \mu \mathrm{m}$. Other features as in the third instar.

Mouthparts. Labrum rounded; about $280 \mu \mathrm{m}$ in width; without punctures. Epipharynx with spines only on lateral portions, up to $5 \mu \mathrm{m}$ long; sensorial area indistinct, but some small and inconspicuous structures similar to basiconic sensilla are present. Mandibles about $230 \mu \mathrm{m}$ long. Maxillary spines very sparse, about $2 \mu \mathrm{m}$ long; maxillary palpi about $15 \mu \mathrm{m}$ long, 20 $\mu \mathrm{m}$ wide; galeae about $18 \mu \mathrm{m}$ long, $23 \mu \mathrm{m}$ wide; spines on lacinial area more sparse than in the third instar, $2-3 \mu \mathrm{m}$ long, contiguous with those on the frontal portion. Labium $280 \mu \mathrm{m}$ wide; spines about 1-2.5 $\mu \mathrm{m}$ long, more sparse than in the third instar; labial palpi greatly reduced. Other features as in the third instar.

\section{First instar (Figs 20-24)}

Body. Length about $2 \mathrm{~mm}$; width about $0.5 \mathrm{~mm}$. Intersegmental lines distinguishable. Pleural lobes slightly developed, laterally jointed. Spiracles $25 \mu \mathrm{m}$ in diameter. Other features as in the second instar.

Head. Height $135 \mu \mathrm{m}$; width about $128 \mu \mathrm{m}$. Other features as in the second instar.

Mouthparts. Labrum somewhat bilobed; $250 \mu \mathrm{m}$ in width, $95 \mu \mathrm{m}$ in height. Epipharynx with spines on lateral and marginal portions, up to $2 \mu \mathrm{m}$ long; median portion with small grains; a sensorial area somewhat distinct, unpigmented, with four basiconic sencilla, about $1.5 \mu \mathrm{m}$ in diameter. Mandibles $188 \mu \mathrm{m}$ long; with three apical teeth, each strongly divided in small denticles. Spines on base of the maxillae not detected; spines on lacinial area up to $3 \mu \mathrm{m}$ long; galeae $20 \mu \mathrm{m}$ long and $25 \mu \mathrm{m}$ wide; maxillary palpi $15 \mu \mathrm{m}$ long and $17 \mu \mathrm{m}$ wide. Labium reduced; with spines, about 1-2 $\mu \mathrm{m}$ long; labial palpi not detected. Other features as in the second instar.

\section{Egg (Fig. 25)}

White. Approximately cylindrical; extremities rounded; one exemplar very slightly curved, other one not curved. Length $2.7 \mathrm{~mm}$; width in the midline $7 \mathrm{~mm}$. Wall smooth.

\section{Cocoon (Fig. 26)}

Wall a one-layer of silk, coated with substance expelled by the larva. Texture as a brittle paper. Claviform, anterior extremity rounded, posterior one tapered. Dark-brown, external surface opaque, internal one brilliant. Meconium cylindrical, narrower distally; isolated from the central portion by a silky wall.

Material examined. BraziL, São Paulo: Ribeirão Preto (Campus of the Universidade de São Paulo, $21^{\circ} 05^{\prime}, 21^{\circ} 15^{\prime} \mathrm{S}$ and $\left.47^{\circ} 50^{\prime}, 47^{\circ} 55^{\prime} \mathrm{W}\right)$, C.A. Garófalo leg. (collected with trap-nests): two eggs, one first instar larva, one second instar larva, one third instar larva, two fourth instar larvae, three mature larvae, two pre-pupa, and four cocoon.

\section{Podium aureosericeum Kohl, 1902}

\section{Mature larva (Figs 27-28)}

Body. Length $16 \mathrm{~mm}$; maximum width $4 \mathrm{~mm}$. Spines on integument 5-13 $\mu \mathrm{m}$ long; setae about $15 \mu \mathrm{m}$ long; setae on prothoracic callosities 13-28 $\mu \mathrm{m}$ long. Pleural lobes developed on segments TII and TIII, absent on segment TI. Spiracles about $120-130 \mu \mathrm{m}$ in diameter. Other features as in the mature larvae of $P$. denticulatum.

Head. Height $1.3 \mathrm{~mm}$; width $1.3 \mathrm{~mm}$. Cephalic rugosity distinct. Parietal bands $70 \mu \mathrm{m}$ long. Antennal orbits circular, $63 \mu \mathrm{m}$ in diameter. Coronal area with 10 punctures, 5-7 $\mu \mathrm{m}$ in diameter, and six setae, $10-20 \mu \mathrm{m}$ long. Frontal area with seven punctures, 4-5 $\mu \mathrm{m}$ in diameter, and six setae, 13-15 $\mu \mathrm{m}$ long. Genal area with about 35 punctures, about $5 \mu \mathrm{m}$ in diameter, and 5-7 setae, 13-18 $\mu \mathrm{m}$ long. Clypeal area with 16 punctures, about $5 \mu \mathrm{m}$ in diameter, and about 15 setae, 9-19 $\mu \mathrm{m}$ long. Other features as in the mature larvae of $P$. denticulatum.

Mouthparts. Labrum $320 \mu \mathrm{m}$ in height, $540 \mu \mathrm{m}$ in width; with 39 punctures, $5 \mu \mathrm{m}$ in diameter, and 30 setae, $11-18 \mu \mathrm{m}$ long; margin with 15 pigmented, barrel-shaped sencilla, about $20 \mu \mathrm{m}$ wide, longer toward the median portion up to $23 \mu \mathrm{m}$ long. Epipharynx with spines on the lateral, marginal and median portions; spines extending beyond the margin; sensorial area with a small area lightly pigmented, with five basiconic sencilla, about 5-7 $\mu \mathrm{m}$ in diameter. Mandibles $590 \mu \mathrm{m}$ long; with small lamellae between the second and the third, and the third and the forth tooth; base with five punctures, $7 \mu \mathrm{m}$ in diameter, and one seta, $18 \mu \mathrm{m}$ long. Spines on maxillae up to $8 \mu \mathrm{m}$ long; lateral and ventral setae 11-21 $\mu \mathrm{m}$ long; maxillary palpi $65 \mu \mathrm{m}$ long, $30 \mu \mathrm{m}$ wide; galeae $83 \mu \mathrm{m}$ long, $30 \mu \mathrm{m}$ wide; spines on lacinial area up to $18 \mu \mathrm{m}$ long. Labium pigmented in lateral portion; $470 \mu \mathrm{m}$ wide; setae on marginal portion up to $25 \mu \mathrm{m}$ long; labial palpi $63 \mu \mathrm{m}$ long, $43 \mu \mathrm{m}$ wide; labial projection $440 \mu \mathrm{m}$ wide. Other features as in the mature larvae of $P$. denticulatum.

\section{Pre-pupa (Fig. 29)}

Body with $12 \mathrm{~mm}$ long and 3,7 $\mathrm{mm}$ in maximum width; other features of the body as in the pre-pupa of $P$. denticulatum. Head and mouthparts as in the mature larva.

Material examined. BraziL, Acre: Senador Guiomard (Reserva Catuaba, area belonging to the Universidade Federal do Acre, $10^{\circ} 04^{\prime}$ S and $67^{\circ} 36^{\prime} \mathrm{W}$ ); E.F. Morato leg. (collected with trap-nests): one mature larva, one pre-pupa.

\section{Podium fumigatum (Perty, 1833)}

\section{Pre-pupa (Fig. 30)}

Body. Length $13 \mathrm{~mm}$; maximum width $3 \mathrm{~mm}$. Spines on integument about $12 \mu \mathrm{m}$ long; setae about 15-25 $\mu \mathrm{m}$ long; se- 
tae on prothoracic callosities $17-20 \mu \mathrm{m}$ long. Pleural lobes somewhat developed on segment TII and TIII, absent on segment TI. Spiracles about $120 \mu \mathrm{m}$ in diameter. Other features as in the mature larvae of $P$. denticulatum.

Head. Height $1.2 \mathrm{~mm}$; width about $1.2 \mathrm{~mm}$. Cephalic rugosity slightly distinct. Parietal bands about $130 \mu \mathrm{m}$ long. Antennal orbits circular, $50 \mu \mathrm{m}$ in diameter. Antennal, frontal, and clypeal concavities unpigmented. Coronal area with eight punctures, $5 \mu \mathrm{m}$ in diameter, and 10 setae, 13-18 $\mu \mathrm{m}$ long. Frontal area with four punctures, about $6 \mu \mathrm{m}$ in diameter, and eight setae, $12-15 \mu \mathrm{m}$ long. Genal area with 23/25 punctures, 5 $\mu \mathrm{m}$ in diameter, and 6/8 setae, $12-23 \mu \mathrm{m}$ long. Clypeal area with 18 punctures, $5-7 \mu \mathrm{m}$ in diameter, and 12 setae, $12-23 \mu \mathrm{m}$ long. Other features as in the mature larvae of $P$. denticulatum.

Mouthparts. Labrum $520 \mu \mathrm{m}$ in width, $210 \mu \mathrm{m}$ in height; with 31 punctures, about 5-7 $\mu \mathrm{m}$ in diameter; 27 setae, 12-23 $\mu \mathrm{m}$ long; margin with 18 barrel-shaped sencilla, about $20 \mu \mathrm{m}$ wide. Epipharynx with spines on lateral and marginal portions up to $18 \mu \mathrm{m}$ long; sensorial area with seven basiconic sencilla, very lightly pigmented. Mandibles $560 \mu \mathrm{m}$ long; with four teeth and small lamellae between the second and third and the third and the forth teeth; base with nine punctures $5 \mu \mathrm{m}$ in diameter, and one seta, about $20 \mu \mathrm{m}$ long. Spines on maxillae up to $5 \mu \mathrm{m}$ long; about 12 setae on lateral and ventral portions, 12 $20 \mu \mathrm{m}$ long; maxillary palpi $65 \mu \mathrm{m}$ long and $68 \mu \mathrm{m}$ wide; galeae $90 \mu \mathrm{m}$ long and $50 \mu \mathrm{m}$ wide; spines on lacinial area up to 15 $\mu \mathrm{m}$ long. Labium $530 \mu \mathrm{m}$ wide; marginal portion with setae, up to $12-28 \mu \mathrm{m}$ long; labial palpi $60 \mu \mathrm{m}$ long, $30 \mu \mathrm{m}$ wide. Other features as the in mature larvae of $P$. denticulatum.

\section{Cocoon (Fig. 31)}

Posterior extremity somewhat rounded. Meconium approximately cylindrical. Other features as in those of $P$. denticulatum.

Material examined. BraziL, Acre: Senador Guiomard (Reserva Catuaba, area belonging to the Universidade Federal do Acre, $10^{\circ} 04^{\prime} \mathrm{S}$ and $67^{\circ} 36^{\prime} \mathrm{W}$ ); E.F. Morato leg. (collected with trap-nests): one pre-pupa and one cocoon.

Remarks. The last instar larvae of $P$. denticulatum is distinct from those of other species of Podium by the lacking of cephalic rugosity. The serrated margin on the third mandibular tooth, which occurs in some specimens of $P$. denticulatum was not observed in other species. Moreover, the cocoon in this species is tapered in the posterior extremity. The somewhat rounded posterior extremity of the cocoon of $P$. fumigatum is similar to those of $P$. fulvipes (Genaro 1994), as those of some species of the related genera Trigonopsis (VARDY 1978) and Sceliphron (Rau 1915, Grandi 1961, Gepp \& Bregant 1986). The last instar larva of $P$. fumigatum and $P$. aureosericeum are unique in bearing small lamellae between mandibular teeth and developed thoracic pleural lobes. P. luctuosum and P. rufipes have cephalic rugosity, but are distinct from the other species in having unpigmented parietal bands (Evans \& LIN 1956, Evans 1964).

\section{ACKNOWLEDGEMENTS}

Sérvio Amarante kindly identified the wasps. The manuscript benefited from the useful comments of Josep Asís and Alcimar do Lago Carvalho.

\section{REFERENCES}

Amarante, S. 2002. A synonymic catalogue of the neotropical Sphecidae and Crabronidae (Hymenoptera: Apoidea). Arquivos de Zoologia, São Paulo, 31 (1): 1-139.

Camilo, E.; C.A. Garófalo \& J.C. Serrano 1996. Biologia de Podium denticulatum Smith em ninhos armadilhas (Hymenoptera: Sphecidae: Sphecinae). Anais da Sociedade Entomológica do Brasil, Londrina, 25 (3): 439-450.

Evans, H.E. 1964. Further studies on the larvae of digger wasps (Hymenoptera: Sphecidae). Transactions of the American Entomological Society, Philadelphia, 90: 235-299.

Evans, H.E \& C.S. Lin. 1956. Studies on the larvae of the digger wasps (Hymenoptera, Sphecidae). Part I: Sphecinae. Transactions of the American Entomological Society, Philadelphia, 81: 131-153.

Genaro, A.G. 1994. Inquilinos de Sceliphron assimile, con énfasis en Podium fulvipes (Hymenoptera: Vespidae, Sphecidae, Megachilidae). Caribbean Journal of Science, Mayagüez, 30 (3-4): 268-270.

Gepp, J. \& E. Bregant. 1986. Zur Biologie der synanthropen, in Europa eingeschleppten Orientalischen Mauerwespe Sceliphron (Prosceliphron) curvatum (Smith, 1870) (Hymenoptera, Sphecidae). Mitteilungen des Naturwissenschaftlichen Vereines fur Steiermark, Graz, 116: 221-240.

Grandi, G. 1961. Studi di un Entomologo sugli Imenotteri superiori. Bolletino del Instituti di Entomologi de la Universidade di Bologna, Bologna, 25: 1-659.

Krombern, K.V. 1967. Trap-nesting wasps and bees: life histories, nests, and associates. Washington, D.C., Smithsonian Press, VI+570p.

Krombein, K.V. 1970. Behavioural and life-history notes on three Floridian solitary wasps (Hymenoptera: Sphecidae). Smithsonian Contribution to Zoology, Washington, D.C., 46: 1-26.

Rau, P. 1915. The differentiation of the cocoons of Pelopoeus caementarius and Chalybion caeruleum. Psyche, Massachusetts, 22: 62-63.

. 1937. A note on the nesting habits of the roachhunting wasp, Podium (Parapodium) carolina Rohwer (Hym). Entomological News, Philadelphia, 48 (4): 91-94.

VARDY, C.R. 1978. A revision of the Neotropical wasp genus Trigonopsis Perty (Hymenoptera: Sphecidae). Bulletin of the British Museum of Natural History (Entomology), London, 37 (4): 117-152.

Received in 08.VIII.2003; accepted in 22.I.2004. 